\title{
1. 産業医キャリア形成からみた専門医の意義1
}

\author{
長井聡里 \\ 産業医科大学産業医実務研修センター
}

\section{【はじめに】}

産業医のキャリア形成において、専属産業医に なることは、所属する企業あるいは事業所の業種 に精通し経験を深め、その積み上げを容易にする。 その一方で、事業所の積極的な社外活動への理解 がなけ扎ば、幅広い見識を得ていくことが困難と なり、キャリアの停滞が生じやすくなる。

そのような立場から専属産業医にとって、本学 会の専門医制度における研修到達目標をすべて網 羅していくには、不利な点も多いが、一方では専 門医制度に登録することによって、事業所に対し 産業医業務への関心を引き出し、信頼性を深める ことにも役立つ。

産業医に関わる様々な資格が存在するなかで、 専属産業医における専門医資格の意義について考 察したい。

\section{【私の経験から】}

私の経歴を簡単に述べると、産婦人科での臨床 経験の後、松下産業衛生科学センターにおいて松 下グループの特殊健康診断等に従事し、その後約 10 年半の間、松下電工秼本社において専属産業医 として從事してきた。従業員数約 6000 人の大規 模事業所で、製造・組立・技術開発・生産技術・ 物流・SE・営業・事務などあらゆる職種が存在し、 本社として電工グループ国内外の統括的立場を求 められることもあった。

産業医となってしばしば遭遇することであるが、 従業員ほか様々な人々から「先生は何科がご専門 ですか？」と質問されることが多い。健康相談で あれば質問意図に㳂うよう臨床科目を告げるが、 ほとんどの場合は挨拶代わりの質問であり、その たびに「産業医学です。」返答し、その反応によ
って「産業医学とは…」の解説を加えることにな る。この素朴な質問こそが、産業医の地位向上の 必要性を痛感する瞬間であり、解説することによ って質問者の満足した反応に、自分のキャリアの 成熟度を確認し自信を深めることにもなっている。 その解説とは、教科書的に産業医学全般につい て述べれば十分なときもあれば、質問者によって は資格について答えねばならないこともある。当 初は産業医科大学に学び、卒後、産業医学基本講 座を履修したことが回答の一つであった。その後、 認定産業医資格が選任要件となり、一般的にも伝 えやすくなった。しかし、本社の室長として統括 的立場を求められたり、大規模で多職種という事 業所の特性から、松下健保スタッフの教育的立場、 産業医科大学の修練医コースの受入れなど、それ までのキャリアでは対応できないスキルを求めら れることも増えていった。そのような中で、本学 会の専門医制度に登録することが、自分自身の系 統的な学習になり、専門医取得に続き、指導医取 得というステップを踏むことによって、さらに事 業所の産業医業務に対する信頼性の向上にもつな がった。

【専属産業医に役立つ資格とその修練】

認定産業医、労働衛生コンサルタント、専門医 の各資格取得のためにどのような修練を行うかを 比較すると、前二者は産業医活動の布石となるよ うな知識の習得が中心であるのに対し、後者は産 業医活動実績そのものが中心となる。前二者があ れば、企業としては少なくとも法的責任を果たす 活動を期待でき、後者があれば学会における各専 門家集団の研究の動向を先取りしながら、最先端 の高度な問題解決能力を期待できる。認定母体の 
違いは、大きくはその修練過程においての情報源 の差であり、指導の広範性・継続性の確保といえ ないだろうか。

専属産業医にとってこれらは、誤解を恐れずに 簡略化してしまうと、まず認定産業医があれば産 業医になることができ、企業に属する限り労㗢衛 生コンサルタントは活用の機会がなく、専門医資 格は消極的には不要であり、積極的には自らの業 績証明として活用できる、と考える。

実際、専門医資格を取得するためには、その研 修手帳に最低 3 年間の活動実績が求められ、記録 に残していく必要がある。この記録に基づいて、 専門医試験では口頭試問等が行われるため、自ら の仕事振りが露呈する。これは当然、所属企業に 対しても業績を明示できる記録であり、雇用する 産業医への信頼性を深めることにもつながる。 一方、専門医資格認定試験の受験資格を得るため、 この研修カリキュラムには産業医実務についても 到達目標が揭げられているが、専属産業医にとつ て、所属企業から専門医資格取得に対する理解が なかったり、勤務する事業所の業種や施設によっ て、これらの経験を積むことが実際上困難となる 場合が往々にしてある。やむを得ないとはいえ、 可能な限り実務修練が積めることを受験生も期待 しているのであって、このようなときに、本学会 の産業医部会プロフェッショナルコースや技術部 会合同セミナ一、産業医・産業看護協議会など、 特に参加型プログラムのような取組みが果たす役 割は大きい。また実務経験を共有し合うようなネ ットワークに参加することも有益であり、これは また医師の卒後教育において単一の医局が果たせ る「場の提供」の限界に対応できるような機能と
考える。

【専門医の果たす役割】

このように専門医資格取得には、指導医をはじ めとする関係者の膨大な協力によって成立する。 このことは認定母体の安定と幅広い各専門家の存 在が不可欠で、産業医業務の特徵をよく示してい る。また、認定試験に合格すると、「これが専門医 の終着点ではなくここからこそが始まり」という 決意を聞くことが多いが、修練によってあらため て産業医業務の奥深さに触れ、生涯研修の必要性 を感じるからだろう。

ところで専属産業医にとって、専門医資格取得 は所属事業所における信頼性の向上以上のメリッ トがあるのだろうか。これについては昨今の経営 環境を考えれば、社会に果たす役割は年々大きく なってきている。雇用形態の多様化、経済の流動 性などは、一事業所の専属産業医として対応でき る限界を超える場合が増えてきた。実際に、小規 模拠点や出向者等の増加による分散事業所的対応、 構内子会社の嘱託産業医対応、グローバル対応な どが求められ、専属として同一レベルの評価や措 置、サービスの提供は困難となってきた。このよ うな変化の速い時代に、専門医としての修練を継 続して積み上げていれば、法改正や異業種の動き など近末来を見据えながら、より社会的立場から の助言指導が可能である。またさらには社会から 求められる産業医像そのものについて機能分化が 進行する可能性もあるのではないだろうか。

【まとめ】

専属産業医として専門医資格は、自身のキャリ ア形成、所属事業所への信頼性、社会に果たす役 割等として、必要な資格である。 